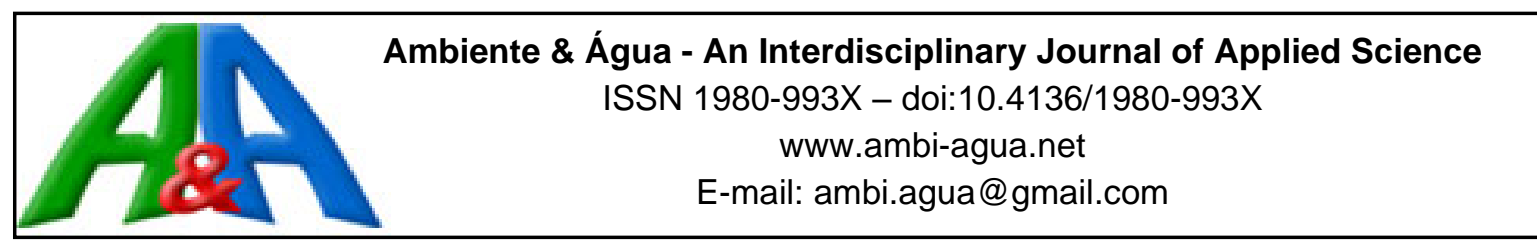

\title{
Sustainability analysis of new household connections to the municipal sewage collection network in Paraná
}

\author{
ARTICLES doi:10.4136/ambi-agua.2419
}

Received: 10 Jun. 2019; Accepted: 17 Dec. 2019

\begin{abstract}
Marlene Alves de Campos Sachet ${ }^{1(i)}$; Patrícia Bilotta ${ }^{2 *}$
${ }^{1}$ Departamento de Governança, Riscos e Compliance. Companhia de Saneamento do Paraná (SANEPAR), Rua Engenheiros Rebouças, n¹376, CEP: 80215-900, Curitiba, PR, Brazil. E-mail: macsachet@gmail.com ${ }^{2}$ Programa de Mestrado e Doutorado em Gestão Ambiental (PGAMB). Universidade Positivo, Rua Professor Pedro Viriato Parigot de Souza, $n^{\circ}$ 5300, CEP: 21280-330, Curitiba, PR, Brazil

*Corresponding author. E-mail: pbilotta@up.edu.br
\end{abstract}

\begin{abstract}
The implementation of sewage collection systems alone does not guarantee public health, since households must be correctly connected to the network in order to derive any benefit from these public works. In order to ensure an environmental and social return on investments in sanitation, a) population must be instructed concerning the role of each citizen, and b) companies responsible for the provision of water and sewage services must be managed in a coordinated and participative manner. This study sought to understand why many households do not respond promptly to the "Connect to the Network" program in the state of Parana and how much the further efforts cost to the sanitation company to regularize this problem. The methodology consisted of analyzing the program's socio-environmental intervention strategies, interviews and service reports for 17 projects (13,286 household connections). The results: no projects achieved $100 \%$ of household connections; total connections were less than $80 \%$ in $40 \%$ of the projects; the additional cost of re-implementing social and environmental initiatives was $\mathrm{R} \$ 680,000.00$. We recommend that user representatives be allowed to participate in the network-deployment process, that social awareness and mobilization strategies be expanded and diversified, and that free home connections be completed for low-income families. This study may aid development agencies to arrive at a standardized methodology for the objective evaluation of socio-environmental initiatives that are to be carried out within the community; it may also aid in the fulfillment of Sustainable Development Goals (SDG), particularly Goal 6 (sanitation services for the entire population).
\end{abstract}

Keywords: sanitary sewer, socio-environmental intervention, wastewater collection.

\section{Análise da sustentabilidade de novas ligações domiciliares à rede municipal coletora de esgotos no Paraná}

\section{RESUMO}

A implantação de redes coletoras de esgoto, por si só, não é garantia de saúde pública, pois os benefícios decorrentes dessas obras dependem também da correta ligação dos domicílios à rede. Esse processo demanda a conscientização da população, sobre o papel de cada cidadão, e a gestão coordenada e participativa das empresas responsáveis pela prestação de serviços de água e esgoto do município, para garantir o retorno ambiental e social dos investimentos em 
saneamento. O objetivo deste estudo foi compreender porque muitas famílias não respondem prontamente ao programa "Se ligue na Rede" no estado do Paraná e quanto custam os esforços para a companhia de saneamento regularizar esse problema. A metodologia consistiu na análise das estratégias de intervenção socioambiental do programa, de entrevistas e relatórios de serviços em 17 empreendimentos (13.286 ligações domiciliares). Como resultado: nenhum dos empreendimentos alcançou 100\% de moradias regularizadas; em 40\% dos empreendimentos as ligações foram inferiores a $80 \%$; o custo adicional para recontratações de ações socioambientais foi $\mathrm{R}$ \$ 680.000,00. Como conclusão, recomenda-se: garantir a participação de representantes dos usuários no processo de implantação de redes; promover a ampliação e diversificação das estratégias de sensibilização e mobilização social; oferecer serviço gratuito de ligação domiciliar à rede para famílias de baixa renda. Este estudo pode auxiliar agências de fomento na consolidação de uma metodologia padronizada de avaliação objetiva das ações socioambientais praticadas junto à comunidade, assim como o cumprimento dos ODS, em especial o Objetivo 6 (saneamento para toda população).

Palavras-chave: coleta de esgoto sanitário, intervenção socioambiental, ligação predial.

\section{INTRODUCTION}

The process of urbanization that began in Brazil in the 1950s has contributed to the degradation of the quality of its urban rivers (Gorski, 2010). One of the main contributing factors associated with this process is the lack of adequate sanitary sewage services (Liliamtis and Mancuso, 2003). In 2015, the United Nations established a blueprint for the purpose of transforming the world, expressed in the form of 17 Sustainable Development Goals (SDG). Goal no. 6, the subject of this article, is to ensure the availability and sustainable management of water and wastewater by 2030. This involves providing access to adequate and equitable sanitation and hygiene for all (UN, 2015). In the Safer water, better health report (WHO, 2009), the World Health Organization (WHO) presents cases of illnesses caused by the absence or inefficiency of a basic sanitation infrastructure, illnesses that could be prevented through the distribution of treated water in conjunction with the collection, transport and treatment of domestic sewage (Pruss-Ustun et al., 2008). Thus, the issues of health and sanitation are directly related, since investments in sanitation reduce the number of deaths and illnesses due to exposure to contaminated water (Souza and Freitas, 2010; Souza et al., 2014).

Moreover, houses that are connected to a sanitary sewer network but improperly discharge their waste into storm drains also contribute to the contamination of water bodies, the generation of foul odors and the persistence of public-health problems (Liliamtis and Mancuso, 2003; Shamsollahi et al., 2019). Thus, the implementation of a sewage collection system alone does not guarantee public health, since households must be correctly connected to the network in order to derive any benefit from these public works. In order to ensure an environmental- and social return on investments in sanitation, the population must be instructed concerning the role of each citizen, and companies responsible for the provision of water and sewage services must be managed in a coordinated and participative manner. Therefore, mobilization initiatives and social participation are essential elements of this process (Lins et al., 2003; Toro and Werneck, 2007). According to Sheely (2015), mobilization is based on the participatory inclusion of the population of a community as the center of action. Both mobilization and participation are seen as means by which certain economic or social demands of the population may be met (Boland and Zhu, 2012; Broeder et al., 2017), gaining necessary support for environmental policies. Therefore, a continuous and structured educational process can promote individual and collective awareness in the community of its role in building and maintaining environmental quality through the correct use of sanitation infrastructures (Dias, 2011; Santos, 2011). 
The State Ministry of Cities in Ordinance 21/14 establishes guidelines for the execution of socio-educational initiatives involving sewage works; these initiatives make use of environmental education concepts and tools to stimulate social participation and improve the living conditions of the population, the effectiveness of social rights and intervention sustainability (the term used to refer collectively to public engineering projects paired with socio-environmental work). These guidelines for social and environmental work are further regulated by Law 11455/07 and Normative Instruction 39/12, which focus on social and environmental sustainability, factors which in turn must be compatible with the basic sanitation plan for river basin planning and management (Brasil, 2007a; 2012, 2014).

In view of these legal provisions, the Brazilian Federal Bank (Caixa Econômica Federal $\mathrm{CEF}$ ), one of the main sanitation agencies in the country, through the "Sanitation for All" Program, has established that interventions in new land connections must include socioenvironmental community initiatives. However, these guidelines provide no details regarding which are the most appropriate practices, leaving to the sanitation companies the responsibility to adopt the measures considered the most appropriate in view of the specific characteristics of each location where an intervention is to be performed, as well as its environment. In addition, the CEF determines an adhesion target of at least $80 \%$ of households correctly connected to the sewage collection system for the project to be considered complete (CEF, 2015).

In response to Normative Instructions 46/07 and 39/12 and Ordinance 21/14 of the federal government (Brasil, 2007b; 2012; 2014), the water and sewage concessionaire of Paraná in 2008 created its own methodology for social and environmental work called the "Connect to the Network" program, in order to establish guidelines for social and environmental intervention in sewage works. This program establishes guidelines for work involving the Technical Project on Socio-Environmental (PTTS), whose objective is to guide the population regarding the theory and practice of environmental sanitation, by means of a socio-educational process that makes use of mobilization and community participation in order to enable social control of new works involving the implementation of a sewage collection network (SANEPAR, 2015). The institutional strategies under the "Connect to the Network" program will be presented in detail in the "Results" section.

It is imperative that the environmental and social return of public investments in sanitary sewage infrastructure be ensured, and social mobilization is an important tool for strengthening shared management through community participation in decisions concerning initiatives that affect its quality of life (Eugenio et al., 2015). Sensitizing a community involves making individuals aware of new possibilities that can impact their lives and the space they occupy, since such sensitization presupposes a work that affects the emotions and foments satisfaction in the care and preservation of the place where one lives (Pereira et al., 2005). In order to sensitize a community regarding basic sanitation issues, educational campaigns must be carried out so that the population understands the importance of individual participation in tasks such as the proper disposal of garbage and human waste (Toro and Werneck, 2007). In addition, an environmental technical survey must be carried out among the households in order to ensure that the residences have been properly connected to the collection network, that is, that the waste generated in the homes is being properly discharged into the sewage collection network, while rainwater is being channeled into the storm drainage network (Bracht, 2007).

In the state of Paraná, whose cities were the object of this study, State Law 13.331/2001 (Article 194) establishes that "all households are required to establish a connection to the sewage collection network as soon as such an opportunity arises" (Paraná, 2001, p.76). In practice, however, this does not occur, and many municipalities in the state of Paraná (such as Castro) show connection rates of approximately 50\%, whereas others (such as Cianorte) achieve a connection rate of $90 \%$, according to information provided by the Paraná sanitation company. Moreover, among the 15 municipalities analyzed in this study, only 2 have 
universalized sewage collection services (100\% connection rate), 4 have connection rates inferior to $50 \%$, and 4 others have connection rates that vary between $50 \%$ and $70 \%$ (Brasil, 2019a).

The aim of this study was to understand why many households do not respond promptly to the "Connect to the Network" program in the state of Parana and how much the further efforts cost the sanitation company to regularize this problem. To achieve this goal, the authors analyzed 15 municipalities in the state of Paraná, which encompass 17 sewage collection projects that have been carried out since the "Connect to the Network" methodology was created. This study may aid development agencies to arrive at a standardized methodology for the objective evaluation of socio-environmental initiatives carried out by sanitation companies within the community.

\section{METHOD}

The research conducted for this work is characterized as a descriptive, quantitative and qualitative study, based on documental analysis using data extracted from a questionnaire applied to the target population. It is also a case study that allows one to understand and explain the relationship and impact of the institutional strategies on the actions of the users, as well as to identify costs involved in raising the awareness of users who did not promptly respond to the program (Yin, 2010). The study was designed to include all municipalities in the state of Paraná (Brazil) that have concluded work on a sewage collection system since the "Connect to the Network" program was created (between 2009 and 2014) and that have household connection rates inferior to $100 \%$ (a total of 13,286 connections). The scope of the study included 15 municipalities: Almirante Tamandaré, Cascavel, Campina Grande do Sul, Campo Mourão, Castro, Cianorte, Colombo, Foz do Iguaçu, Paranavaí, Pinhais, Piraí do Sul, Pitanga, Quatro Barras, Teixeira Soares, and Ubiratã. This study was divided into three steps in order to reach the proposed goal: 1) analysis of the socio-environmental actions under the "Connect to the Network" program; 2) analysis of the socio-environmental items in the questionnaire applied to the target population (see annex); 3) calculation of the additional cost generated by further efforts necessary to raise awareness among users who did not respond promptly to the "Connect to the Network" program. Each step is described in detail below.

\subsection{Socio-environmental strategies under the "Connect to the Network" program}

The first step consisted of evaluating the socio-environmental intervention strategies established by the "Connect to the Network" program toward the community that will benefit from the sewage collection and treatment works. For this analysis, the following documents were consulted: the institutional "Reference Term" for contracting socio-environmental actions (SANEPAR, 2015); the financing contracts for the implementation of the sewage systems in the 15 selected municipalities; the "Technical Projects of Socio-Environmental Works", which describes the planning of initiatives carried out within the communities and includes their respective opinions and follow-up reports; the guidelines of the "Manual for the Promotion of the Federal Savings Bank" (Sanitation for All Program) (CEF, 2015); the requirements regarding the composition of the technical team assigned to carry out the socio-environmental initiatives, as defined in Administrative Rule no. 21/14 (Brasil, 2014).

\subsection{Socio-environmental analysis of the target population}

The objective of the second stage of this study was the identification of the socioenvironmental elements that influence the effectiveness of the program at each of the intervention sites, that is, for each new project involving the implementation of a sewage collection network. For this purpose, the socio-environmental data of the target population were 
collected from a structured questionnaire (annex) applied during the implementation of the sewage collection system in all 15 municipalities studied (13,286 households). The information collected was as follows: 1) socio-economic profile (average family income and any social program in which the family is enrolled); 2) general knowledge of the local residents about the sewage system (regarding the importance of the collection and treatment of sewage); 3 ) the cost of installing a connection to the sewage collection system; 4) the proper way in which the connection of the home network to the sewage system must be carried out; 5) the procedure used by the water and sewage company when inspecting the property to verify the existence of a proper connection to the network; 6) the existence of Law 13.331/2001, Art. 179/194, which requires all properties to have a connection to the sewage system, provided such a network is available; and 7) the procedures in place regarding the properties that have not been connected to the system after the surveys, including potential notifications sent to the resident and sanctions imposed by the sanitary surveillance of the municipality or local green police should the resident fail to connect his residence to the sewage collection system).

\subsection{Additional Costs}

In order to determine additional costs incurred by the sanitation company due to potential reactivation of social and environmental initiatives in order to raise awareness among users who did not respond promptly to the "Connect to the Network" program, the costs of technical surveys and programs for raising environmental awareness were used. From this survey, the additional financial cost was calculated per project for the period studied.

\section{RESULTS AND DISCUSSION}

Table 1 presents the data for the 17 projects in the 15 municipalities studied regarding the status of the 13,286 household connections (projects) carried out.

Table 1. Status of the projects analyzed.

\begin{tabular}{lccc}
\hline \multirow{2}{*}{ MUNICIPALITY } & \multicolumn{2}{c}{ NUMBER OF HOUSEHOLD SEWAGE CONNECTIONS } \\
\cline { 2 - 4 } & AVAILABLE & \multicolumn{2}{c}{ REGULARIZED } \\
\hline Almirante Tamandaré & 200 & 131 & $65.5 \%$ \\
Cascavel & 2,671 & 2,276 & $85.2 \%$ \\
Campina Grande do Sul & 253 & 156 & $61.7 \%$ \\
Campo Mourão & 915 & 785 & $85.8 \%$ \\
*Castro (I) & 683 & 377 & $55.2 \%$ \\
*Castro (II) & 289 & 175 & $60.5 \%$ \\
Cianorte & 610 & 553 & $90.7 \%$ \\
Colombo & 583 & 480 & $82.3 \%$ \\
Foz do Iguacu & 2,990 & 2,623 & $87.7 \%$ \\
Paranavaí & 706 & 570 & $80.7 \%$ \\
Pinhais & 708 & 687 & $97.0 \%$ \\
Pirai do Sul & 591 & 473 & $80.0 \%$ \\
Pitanga & 1,013 & 889 & $87.8 \%$ \\
*Quatro Barras (I) & 155 & 82 & $80.4 \%$ \\
*Quatro Barras (II) & 127 & 95 & $74.8 \%$ \\
Teixeiras Soares & 304 & 247 & $74.8 \%$ \\
Ubiratã & 488 & 404 & $82.8 \%$ \\
\hline TOTAL & 13,286 & 11,003 & $78.4( \pm 11.2) \%$ \\
\hline
\end{tabular}

*Municipality with more than one financing agreement with funding agency.

The results showed a variation between $55.2 \%$ and $97.0 \%$ regularization of household connections, with none of the projects having achieved $100 \%$ household connection to the

\section{IPABH}


sewage network. Moreover, $40 \%$ of the 17 projects analyzed did not reach the goal of $80 \%$ established by the development agency (Caixa Econômica Federal) for sanitary sewage infrastructure. The overall average of regularized connections was $78.4 \%$.

\subsection{Analysis of the socio-environmental intervention strategies}

The institutional actions under the "Connect to the Network" program are summarized in Table 2.

Table 2. Strategies under the "Connect to the Network" program.

\begin{tabular}{ll}
\hline TYPE OF INITIATIVE & \multicolumn{1}{c}{ DESCRIPTION } \\
\hline Community meeting & $\begin{array}{l}\text { An initiative carried out among the residents of the project site in order to initiate } \\
\text { a dialogue with the population, including a presentation of the engineering project } \\
\text { and social technical work, a description of its benefits for the population and the } \\
\text { environment and an explanation regarding the role of the citizens in this process. }\end{array}$ \\
\hline $\begin{array}{l}\text { Socio-environmental } \\
\text { agents }\end{array}$ & $\begin{array}{l}\text { The training of community leaders, health surveillance inspectors, community } \\
\text { health agents, educators, etc., in order to train information and knowledge } \\
\text { multipliers for work with the population. }\end{array}$ \\
\hline
\end{tabular}

A visit made to each residence involved in the project after the community

$\begin{array}{ll}\text { Environmental awareness } & \text { meeting. In this phase, a socio-environmental agent visits the dwellings in order } \\ \text { to underscore the need for sustainable environmental behaviors on the part of the }\end{array}$ population and to highlight the role of the user regarding the deployment of the sewage collection network, as well as to conduct a survey of the residents.

A visit to the houses among the population to authorize the household connection

Accession to the project to the sewage collection network, accompanied by the delivery of an instructional kit containing information explaining how to carry out this procedure.

An evaluation of the conditions of home connections to the sewage network, conducted by applying dyes in each compartment (toilets, sinks, drains, rainwater). The residence is considered to be properly connected to the system

Environmental technical when its effluents are discharged into the collection network, rainwater is directed survey to the storm drains, septic tanks and cesspits are deactivated, and the house has been equipped with a grease trap that conforms to the standards adopted by the local prefecture and meets the requirements set forth in ABNT 8160/1999.

Technical orientation for Follow-up socio-educational work conducted by the socio-environmental agent the user in homes that did not regularize their situation. In this phase, the agent reiterates the importance of commitment to the population.

Course

Training for plumbers and stonemasons residing in the area of the project to work with the community in servicing home connections.

Socio-environmental survey

The application of a structured survey developed by a team of social workers, sociologists, statisticians and socio-environmental managers for the purpose of evaluating the community's understanding of the actions taken.

Educational kit

Distribution of didactic material to the population regarding important issues related to environmental sanitation (water, sewage, garbage, urban drainage and health).

Although the company took an active stance in the elaboration of strategies for a socioenvironmental approach toward the population serviced by the new sewage collection networks, no effective participation of the population in the planning process for the implantation of the collection network was observed in the analyzed projects (Struecker et al., 2017). This fact may have contributed to the lack of $100 \%$ regularization of home connections to the collection network seen in Table 2. The purpose of community involvement in the 
planning of a new project is to guarantee the effectiveness of the initiative for connecting households to the collection network. In this regard, social and environmental work is expected to achieve remarkable results, provided there exists an active (not passive) understanding and participation of the community in the process (Struecker et al., 2017). This is in line with the recommendations of the Environmental Education and Social Mobilization in Sanitation Program of the State Ministry of Cities, which addresses socio-environmental intervention in sanitation conducted before, during and after the works have been completed (Brasil, 2009). In addition, Ordinance no. 21/14 of the Ministry of Cities reinforces the importance of joint formulation of social solutions, with an emphasis on participatory activities such as community meetings, workshops, etc., in order to promote the participation of the population in the planning and execution of social and environmental initiatives (Brasil, 2014).

According to the methodology used by the "Connect to the Network" program, one of the first actions taken during the intervention should be the formation of a management group during the period prior to the beginning of the project and the community meetings. This group is to be formed soon after the signing of the service order. However, it was observed that after 2011 the formation of management groups was no longer carried out, despite the fact that there is no record of a thoughtful analysis on the part of the process managers concerning the impact of removing this step from the scope of the social and environmental works. This should have been a key consideration since the role of this group is based on community participation during the execution of the projects, communicating the relevant information to all those involved (Struecker et al., 2017).

It is imperative that training and meetings with management groups be resumed, since these groups leverage social mobilization as a result of the effective participation of their members in the society. Mobilization must be seen as a collective action in which the participation of responsible and conscious agents and the use of strategies and decisive decisions work together to consolidate a particular project (Pacheco, 2011; Hassan et al., 2010; Struecker et al., 2017). The management group acts as a link between the project and the community, providing up-to-date information regarding what is happening during the execution of the project, in addition to promoting public policies and explaining their benefits, especially for the low-income population (Eugenio et al., 2015, Broeder et al., 2017; Hassan et al., 2010).

The first contact of socio-environmental agents with the community occurs in the community meeting. At this stage, a dialogue is initiated in order to inform the users regarding the benefits of installing a sewage collection system and land connections, with the aim of socializing information of common interest, developing the community and clarifying its role in promoting the environmental sustainability and social impact of the enterprise. Krug (1984) and Schmitt et al. (1999) point out that a community meeting is one of the means used to raise public awareness and strengthen its link with the environment, health and quality of life after the establishment of the collection network. According to the strategies under the "Connect to the Network" program (Table 2), the community meetings must take place 30 days before implementation of the sewage collection system begins. However, the reports analyzed revealed not only the lack of any community meetings in 5 of the municipalities, but also that the number of meetings that were held was lower than the minimum laid out in the "Connect to the Network" methodology (1 for every 250 households) Hassan et al. (2010). This fact may have contributed to the non-compliance. In view of these findings, it is suggested that community meetings be held in all new ventures and that the criteria used to define the number of meetings necessary to reach its goal toward the population should be reevaluated. Moreover, community meetings must be held prior to the commencement of the civil works in order to inform residents regarding the benefits of network deployment, as well as regarding the inconvenient impacts that may also result from civil works, such as sidewalk cracking, asphalt removal, etc. (Leff, 2000). It is also important that broader and more effective communication channels (radio 
stations, local newspapers, social networks) be employed in order to encourage as many families as possible to participate in the meetings (Nehme et al., 2014). Therefore, new techniques such as recreational workshops to reinforce the community awareness process must be implemented in addition to those already known (community meeting), in order to sensitize the community regarding the importance of the participation of the population in the implementation of the sewage collection network, with the aim of making them collaborators in the preservation of the environment, assuming their co-responsibility, so that their children and grandchildren enjoy a quality of life (Paviani and Fontana, 2009). It is also important to create an evaluation process after the meetings in order to compare the planned initiatives with those actually executed and identify any points that may be improved.

The second contact of socio-environmental agents with the community occurs in the home visit for the purpose of raising environmental awareness. In this step, the families are visited individually for a conversation about the implementation of the public work and the procedure for connecting their home to the collection network (Kamaruddin et al., 2016). It is during this meeting that a socio-environmental questionnaire is filled out by the resident. This meeting was in fact carried out in all instances studied; but it was observed that in each case the visits were carried out outside the term stipulated in the Term of Reference. According to the Term of Reference, this step should occur soon after the community meeting, preferably before the beginning of the civil work, since it is at this point that the community will be the most engaged and looking forward to the benefits brought by the public work, thus potentially yielding more promising results (Faya and Paganini, 2013). According to Santos and Ota (2002), the procedure for tabulating questionnaire responses must also be created, enabling this information to be used for defining new socio-environmental intervention policies and identifying which families fall within the social tariff program (and thus are exempt from paying for water and sewage services).

The commercialization of the sewage connection to the user occurs by means of a home visit whose goal is adherence to the project, this visit being conducted by the sanitation company's own staff. Employees involved in this activity should be trained and educated concerning the impact of inappropriate sensitization (Hassan et al., 2010). The environmental technical survey consists of verifying the connection of the household to the sewage system. This test is conducted using dyes (green, yellow, blue and red) applied to the kitchen sink and toilet in the residences in order to determine the destination of the sewage. The methodology stipulates that this service should be carried out as soon as the adhesion is complete; however, the analysis of the reports and questionnaires revealed that for $86.84 \%$ of the residences visited, these services occurred months or even years later. A change in methodology in 2012 introduced a new step before the surveys, calling for a home visit for the purpose of technical customer orientation, whose aim was to create a more personalized experience for the community while providing guidance regarding a proper house connection to the sewage collection system. However, such a technical orientation for the client would be wholly unnecessary if the sensitization initiatives were actually being carried out within the deadlines stipulated in the Term of Reference. The authors therefore suggest that an evaluation be conducted to determine whether this service is truly necessary, since the work that should precede it would render it unnecessary (Uzun and Keles, 2012).

In order to mobilize leaders such as school teachers, health workers, community leaders, etc., at the intervention site, the "Connect to the Network" methodology establishes a training course for the socio-environmental agents, having a workload of up to 20 hours and a maximum of 30 students per class. This course aims to train socio-environmental agents to act as multipliers of knowledge concerning the relationship between human health and a change in the attitude of the population toward the environment; however, only one municipality, Foz do Iguaçu, actually held the course (Uzun and Keles, 2012). When planning the training of socio- 
environmental agents, it is important to encourage the participation of as many people as possible from the community, in order to identify entities that can participate in the socioenvironmental education processes regarding sanitation. Another way to make the agent feel that he is part of the process that he will later replicate is to stimulate the use of workshops during the courses (Bernardes, 2007; Uzun and Keles, 2012).). In view of these observations, it is suggested that these courses actually be provided ( 1 for every 2,500 houses), considering that only $53 \%$ of the enterprises studied make provision for such an initiative in their financing agreement.

Regarding training for plumbers and masons in the community, the analysis revealed that $72 \%$ of the projects did not anticipate such courses in the financing contract, $1 \%$ of the projects actually held the courses, and the remaining $27 \%$ of the financing contracts did not actually execute this step, although it was provided for in the contract. Figure 1 presents an overview of the socio-environmental initiatives carried out in the projects analyzed. This chart clearly shows a decline in the number of meetings with both the community and the management group, as well as in the number of courses offered for the training of socio-environmental agents and plumbers. Technical guidance to users and sporadic surveys (Figure 2) were included in 2013 and 2014, respectively, but these actions were not enough to guarantee compliance, since connections did not achieve $100 \%$.

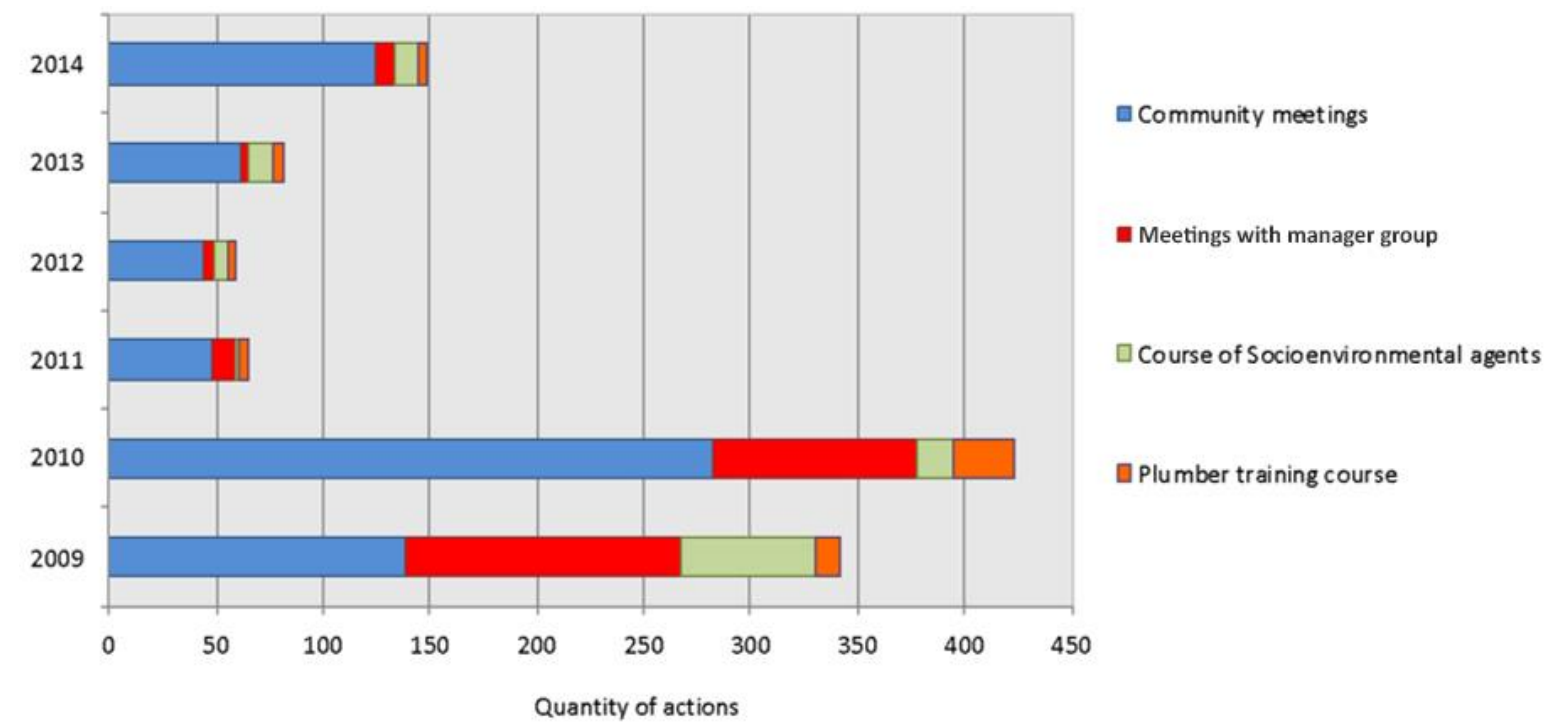

Figure 1. Socio-environmental initiatives carried out in the projects analyzed.

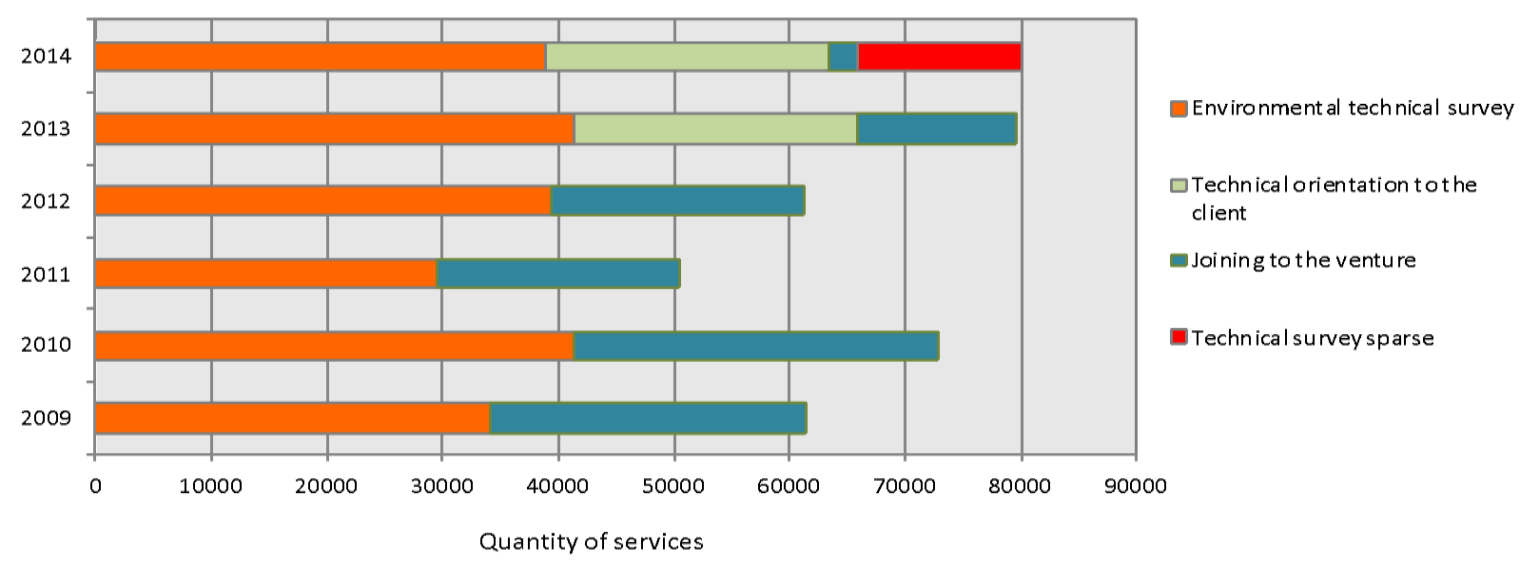

Figure 2. Technical services performed in the projects analyzed.

\section{IPABH}


In order to improve training courses (for plumbers and stonemasons), partnerships should be established with local institutions to absorb skilled labor, especially professionals working in their profession. It is of utmost importance that the course be carried out before the environmental technical surveys. It is therefore suggested that an assertive timetable be created, so that the course can be carried out in the month preceding the surveys, thus allowing the plumber to work with the community in a timely manner to provide the service of connecting the dwelling to the collection system in a manner that is cost-appropriate to the local economic reality (Uzun and Keles, 2012).

The pedagogical support material should seek to present in a didactic manner the details regarding sanitary sewage works, their advantages and the initial impacts they may cause. However, in practice, the didactic material used by the sanitation company in the socioenvironmental actions carried out between 2009 and 2014 was summarized in an orientation folder describing the residential connection to the network, distributed at the time of the residence accession to the project and redistributed during the orientation to the customer. It is suggested that the teaching material be revised and reprinted to produce a kit composed of booklets having the following themes: water, sewage, solid waste, health, urban drainage, environmental awareness, adherence to the project and technical surveys (Uzun and Keles, 2012).

The strategies used in the monitoring of the socio-environmental services should be reviewed. From the Term of Reference and Technical Project of Socio-Environmental Work, it is recommended that indicators be created that are organized by type of service and monthly goals. It is imperative that dynamic and interactive methods be implemented in order to evaluate the true extent of the information actually transmitted to the population during the social and environmental services. Promoting educational projects that go beyond formal educational spaces may contribute to the learning and awareness of the population, in addition to strengthening social participation, resulting in a positive impact on the number of connections made to the sewage collection system (Silva and Naval, 2015).

\subsection{Analysis of Socio-Environmental Factors}

Table 3 presents a summary of the socioeconomic status of the households in the 17 enterprises studied. The results from this analysis revealed that $71.10 \%$ of the households interviewed lived on incomes of less than 2 minimum wages; thus, these are families who fit a low-income profile. Moreover, $27.71 \%$ of the households received benefits from the Federal Government's Bolsa Família Program to guarantee their subsistence, 26.11\% were enrolled in the "Luz Fraterna" program (Paraná, 2013) and 17.97\% participated in the "Leite das Crianças" program (Paraná, 2010), the last two being programs provided by the government of the state of Paraná.

The analysis of the questionnaires further revealed that $20.9 \%$ of the families interviewed were beneficiaries of the social tariff for water and sewage services (Paraná, 2004) and 28\% were registered in the Bolsa Família, government food program. Therefore, family income may be a limiting factor that contributes to the non-regularization of land connections. The granting of an exemption for low-income families and those registered in social programs from fees for connecting the dwelling to the sewage collection network (that is, fully subsidizing the costs involved) is a strategy that could be used to encourage socially vulnerable users to comply with the request to regularize their sewage connections. Table 4 shows the results of the interviews, whose goal was to evaluate the understanding of the network user regarding the importance of sewage collection in his community and regarding his legal obligation to properly connect to the sewage network. 
Table 3. Analysis of the socioeconomic status of the families interviewed.

\begin{tabular}{lccc}
\hline \multirow{2}{*}{ MUNICIPALITY } & \multicolumn{2}{c}{ HOUSEHOLD INCOME } & SOCIAL PROGRAM \\
\cline { 2 - 4 } & $*<0.5$ Minimum wage (\%) & $* 1$ to 2 minimum wages (\%) & $\begin{array}{c}\text { Receive household } \\
\text { social assistance }(\%)\end{array}$ \\
\hline Almirante Tamandaré & 8.0 & 0.0 & 6.5 \\
Campina Grande do Sul & 48.7 & 63.7 & 26.5 \\
Campo Mourão & 2.4 & 59.1 & 17.0 \\
Cascavel & 0.8 & 59.0 & - \\
$* *$ Castro I & 11.2 & 43.8 & 2.4 \\
$* *$ Castro II & 4.8 & 48.5 & 14.5 \\
Cianorte & 0.2 & 45.6 & 4.0 \\
Colombo & 10.5 & 0.0 & 9.9 \\
Foz do Iguaçu & 7.5 & 61.5 & 40.0 \\
Paranavaí & 1,3 & 62,4 & 8,8 \\
Pinhais & 8,3 & 0,0 & 7,3 \\
Piraí do Sul & 3,0 & 61,8 & 15,8 \\
Pitanga & 6,0 & 87,5 & 32,5 \\
**Quatro Barras (I) & 10,4 & 27,2 & 38,5 \\
$* *$ Quatro Barras (II) & 1,0 & 51,9 & 25,0 \\
Teixeira Soares & 74,4 & 70,0 & 32,5 \\
Ubiratã & 5,1 & 0,0 & 2,1 \\
\hline
\end{tabular}

*Current Brazilian Minimum Salary: R\$ 998.00 (U\$ 236.76 in November 25, 2019) (Brasil, 2019b).

$* *$ Municipality with more than one financing agreement with funding agency.

Table 4. Results of the questionnaire applied to the target population.

\begin{tabular}{|c|c|c|c|c|c|c|}
\hline \multirow[b]{2}{*}{ MUNICIPALITY } & \multicolumn{6}{|c|}{ QUESTIONS ON THE QUESTIONNAIRE } \\
\hline & $\begin{array}{l}\text { 1. Collected } \\
\text { and treated } \\
\text { sewage }(\%)\end{array}$ & $\begin{array}{l}\text { 2. Cost of } \\
\text { sewage } \\
\text { connection } \\
(\%)\end{array}$ & $\begin{array}{l}\text { 3. Proper } \\
\text { home } \\
\text { connection to } \\
\text { the network } \\
(\%)\end{array}$ & $\begin{array}{l}\text { 4. Method } \\
\text { used for } \\
\text { inspecting } \\
\text { home } \\
\text { connection } \\
(\%)\end{array}$ & $\begin{array}{l}\text { 5. Law } \\
\text { requiring } \\
\text { connection to } \\
\text { the network } \\
(\%)\end{array}$ & $\begin{array}{c}\text { 6. Penalties } \\
\text { for irregular } \\
\text { connections } \\
(\%)\end{array}$ \\
\hline Almirante Tamandaré & 80.0 & 84.0 & 80.0 & 81.5 & 94.0 & 79.0 \\
\hline Campina Grande Sul & 75.6 & 77.9 & 77.9 & 76.7 & 76.7 & 76.7 \\
\hline Campo Mourão & 76.6 & 73.5 & 72.9 & 69.1 & 70.7 & 69.1 \\
\hline Cascavel & 4.1 & 15.7 & 18.1 & 17.0 & 15.7 & 16.5 \\
\hline *Castro (I) & 48.0 & 19.4 & 31.6 & 31.8 & 47.2 & 30.2 \\
\hline *Castro (II) & 37.0 & 10.3 & 20.4 & 27.0 & 48.4 & 33.2 \\
\hline Cianorte & 0.0 & 0.0 & 0.0 & 0.0 & 0.0 & 0.0 \\
\hline Colombo & 64.9 & 67.2 & 67.2 & 64.3 & 64.3 & 63.7 \\
\hline Foz do Iguaçu & 15.6 & 10.6 & 11.8 & 14.7 & 14.5 & 13.5 \\
\hline Paranavaí & 63.9 & 22.0 & 53.5 & 68.5 & 76.1 & 60.0 \\
\hline Pinhais & 81.5 & 1.5 & 86.4 & 82.5 & 84.5 & 83.5 \\
\hline Piraí do Sul & 60.3 & 35.7 & 55.2 & 60.8 & 54.5 & 52.8 \\
\hline Pitanga & 13.7 & 4.8 & 6.3 & 14.8 & 15.1 & 15.1 \\
\hline *Quatro Barras (I) & 14.4 & 14.2 & 14.3 & 14.3 & 14.2 & 14.3 \\
\hline *Quatro Barras (II) & 14.2 & 14.3 & 14.1 & 14.1 & 14.4 & 4.4 \\
\hline Teixeira Soares & 10.0 & 98.8 & 100.0 & 98.8 & 97.6 & 96.4 \\
\hline Ubiratã & 81.4 & 77.4 & 45.1 & 2.7 & 22.1 & 20.0 \\
\hline
\end{tabular}

*Municipality with more than one financing agreement with the funding agency.

According to the results from the questionnaires, in 6 of the 17 ventures less than $50 \%$ of respondents were knowledgeable about the information asked. This reveals a limitation in the effectiveness of the socio-environmental intervention steps of the "Connect to the Network" program with regard to the transfer of knowledge concerning the importance and the proper manner of home connection to the sewage collection network for the resident population in the place of implantation of the enterprise. However, despite the fact that the interviewees did not exhibit adequate knowledge regarding the sewage collection enterprise, in each of these cases (with the exception of Castro I and II and Quatro Barras II) the percentage of regularized 
connections was higher than $80 \%$. In the municipality of Cianorte, the interviews were not conducted. The projects showing the best results (above 80\% regularized households) were Almirante Tamandaré, Pinhais and Teixeira Soares. However, when the results from the questionnaires (Table 4) were crossed with the results from the analysis of the number of regularized land connections (Table 2), it was observed that only the municipality of Pinhais presented a percentage of sewage connections above $80 \%$. This reveals a discrepancy between the knowledge that the respondents claimed to have regarding the subject and their effective action in response to the requirement of having a proper home connection to the sewage collection network (Kamaruddin et al., 2016).

It is suggested that a field survey be carried out among the users after the completion of the network deployment in order to identify their perception of the services performed and to establish measures for improvement in future projects. However, it is recommended that such a study be carried out by a company other than the one responsible for the social and environmental actions and services, in order to guarantee impartiality in the evaluation of the activities performed.

In addition to the aspects mentioned above, it is important that social workers or sociologists be included on the technical team responsible for the socio-environmental actions of new project for the purpose of improving the quality of the services provided to the sewage collection network users.

Finally, stronger measures should be developed and applied to users who, even after orientation and awareness efforts, do not adhere to the request to regularize their household connection to the sewage system. It is considered necessary to establish a procedure for prosecuting cases of non-compliance at the Public Prosecutor's Office and Sanitary Surveillance, institutions that have the power to fine the non-compliant homes.

\subsection{Quantification of Additional Financial Costs}

The analysis of the additional costs incurred by the "Connect to the Network" program in order to achieve an index of $100 \%$ households properly connected to the sewage collection system, that is, full user membership, revealed an increase in cost due to re-implementation of the awareness and technical environmental connection survey of between $3.8 \%$ and $200.4 \%$ (depending on the number of initiatives that need to be re-contracted), in relation to the value initially contracted for the 17 projects (a total additional cost of $\mathrm{R} \$ 680,000.00$ ). Although in some cases a single re-contracting was sufficient, others required two or even three repetitions to bring about the regularization presented in Table 2. The following projects exhibited the highest additional costs: Pitanga (200.4\%), Almirante Tamandaré (183.2\%), Campo Mourão (130.7\%), Piraí do Sul (129.2\%) and Quatro Barros I (123.6\%). However, none of them achieved a regularization of more than $90 \%$ (Pitanga: $87.8 \%$ ), Almirante Tamandaré: $65.5 \%$, Campo Mourão: $85.5 \%$, Piraí do Sul: $80.0 \%$, and Quatro Barras I: $80.4 \%$ \%). Even with the additional cost, none of the 17 projects analyzed achieved $100 \%$ regularization of sewage connections (Dominick and Diulio, 1981).

Ensuring a totality of regularized connections $(100 \%)$ is a matter of great importance, since it is essential for promoting public health and environmental quality (irregular connections may be associated with the contamination of soil, rivers and groundwater), as already discussed (Shamsollahi et al., 2019). The Federal Brazilian Bank (Caixa Econômica Federal) currently considers $80 \%$ to be the minimum goal for regularization of pre-existing connections to sanitary sewage infrastructure (CEF, 2015). Based on the results obtained, failure to meet this goal may be related to the following three main factors: insufficient assimilation of the information transmitted to the population; a lack of understanding of the information passed on by the socioenvironmental agents during the sensitization phase; and the socioeconomic conditions of network users. 


\section{CONCLUSION}

In order for the benefits of the sewage system to be perceived by the population, it is imperative that water and sewage service companies promote socio-environmental actions among the community (Mei et al., 2016). The implantation projects for sewage collecting networks must go through a process of participatory planning in conjunction with the population, beginning with the stage of identifying the needs of the local community, through the execution and subsequent deployment stages of the enterprise to the users (UN, 2019). None of the 17 development projects analyzed (13,286 land links) obtained 100\% regularized home connections. In $40 \%$ of the projects, regularization was lower than the $80 \%$ goal established by the development agency, and the additional cost paid by the water and sewage company of Paraná to re-implement social and environmental initiatives toward the population that did not adhere promptly to the requirement of a home connection to the sewage collection network was $\mathrm{R} \$ 680,000.00$.

The socio-environmental actions contracted in the projects analyzed were not executed as planned. Moreover, the "Connect to the Network" program does not fit the framework of an effective socio-environmental program, as may be concluded from the predominance of technical services (surveys, guidelines and accession) as compared to educational and informative socio-environmental initiatives (community meetings, meetings with the managing body, courses for socio-environmental agents, plumber training courses). It is understood that this factor, together with the low household income of the users in the analyzed projects, may have contributed to the non-compliance regarding connections to the sewage collection network (Kamaruddin et al., 2016).

It is recommended that the participation of representatives of the users in the process of network deployment be ensured in order to promote the expansion and diversification of the social awareness and mobilization strategies, and that a free home connection to the network be provided for low income families (Kamaruddin et al., 2016). Since no specific guidelines exist to direct the companies that provide sanitary sewage services with regard to the users of the sewage collection systems, this study can help aid development agencies to arrive at a standardized methodology for the objective evaluation of socio-environmental initiatives to be carried out within the community. For future research, it is recommended that the socioenvironmental initiatives carried out within the framework of the "Connect to the Network" program be compared with similar initiatives that are planned and executed with sanitation companies in other Brazilian states.

\section{REFERENCES}

BERNARDES, J. C. J. Oficina lúdica de educação sanitária: outra forma de abordagem para a mobilização de comunidades. In: CONGRESSO BRASILEIRO DE ENGENHARIA SANITÁRIA E AMBIENTAL, 24., 02 a 07 de setembro de 2007, Belo Horizonte. Proceedings[...] Rio de Janeiro: ABES, 2007.

BOLAND, A.; ZHU, J. Public participation in China's green communities: Mobilizing memories and structuring incentives. Geoforum, v. 43, n. 1, p. 147-157, 2012. https://doi.org/10.1016/j.geoforum.2011.07.010

BRACHT, C. C. A ligação predial de esgotos sanitários como fator de preservação da qualidade da água de rios urbanos. In: CONGRESSO BRASILEIRO DE ENGENHARIA SANITÁRIA E AMBIENTAL, 24., 02 a 07 de setembro de 2007, Belo Horizonte. Proceedings[...] Rio de Janeiro: ABES, 2007. 
BRASIL. Presidência da República. Lei n. 11.445, de 5 de janeiro de 2007. Estabelece as Diretrizes Nacionais para o Saneamento Básico. Diário Oficial [da] União: seção 1, Brasília, DF, 8 jan. 2007a.

BRASIL. Ministério das Cidades. Instrução Normativa n. 39, de 24 de outubro de 2012. Regulamenta os procedimentos e as disposições relativos às operações de crédito no âmbito do Programa Saneamento para Todos. Diário Oficial [da] União: seção 1, Brasília, DF, n. 207, p. 84, 25 out. 2012.

BRASIL. Ministério das Cidades. Instrução Normativa n. 46, de 10 de outubro de 2007. Regulamenta os procedimentos e as disposições relativas às operações de crédito no âmbito do Programa Saneamento Para Todos. Diário Oficial [da] União: seção 1, Brasília, DF, 11 out. $2007 b$.

BRASIL. Ministério das Cidades. Portaria n. 21, de 22 de janeiro de 2014. Aprova o Manual de Instruções do Trabalho Social nos Programas e Ações do Ministério das Cidades. Diário Oficial [da] União: seção 1, Brasília, DF, n. 16, p. 39, 23 jan. 2014.

BRASIL. Ministério das Cidades. Secretaria Nacional de Saneamento Ambiental. Caderno metodológico para ações de educação ambiental e mobilização social em saneamento. Brasília, 2009.

BRASIL. Ministério do Desenvolvimento Regional. Sistema Nacional de Informações sobre Saneamento. Diagnóstico dos Serviços de Água e Esgotos 2017. Brasília, 2019a.

BRASIL. Presidência da República. Decreto n. 9.661, de $1^{\circ}$ de janeiro de 2019. Aprova o salário mínimo de 2019. Diário Oficial [da] União: seção 1, Brasília, DF, p. 15, 01 jan. 2019b.

BROEDER, L.; UITERS, E.; HAVE, W.; WAGEMAERS, A.; SCHUIT, A. J. Community participation in Health Impact Assessment. A scoping review of the literature. Environmental Impact Assessment Review, v. 66, p. 33-42, 2017. https://doi.org/10.1016/j.eiar.2017.06.004

CAIXA ECONOMICA FEDERAL. Manual de Fomento: saneamento para todos. Brasília, 2015.

DIAS, G. F. Educação ambiental, princípios e práticas. 9. ed. São Paulo: Gaia, 2011.

DOMINICK, S.; DIULIO, E. A. Introdução a economia. São Paulo: Schaum McGraw-Hill, 1981.

EUGENIO, J. L.; MENDONZA, M. L. M.; FIGUEROA, I. V.; AMEZCUA, J. M. M. Movilización social y determinantes sociales de la salud: proceso educativo en comunidad rural de Jalisco, México. Estudios Sociales, v. 23, n. 46, p. 139-161, 2015.

FAYA, O. E. N.; PAGANINI, W. S. Degradação ambiental e qualidade de vida das populações dos manguezais: potenciais benefícios decorrentes da mobilização social e da educação ambiental. In: CONGRESSO BRASILEIRO DE ENGENHARIA SANITÁRIA E AMBIENTAL, 27., 15 a 19 de setembro de 2013, Goiânia, GO. Proceedings[...] Rio de Janeiro: ABES, 2013.

GORSKI, M. C. B. Rios e cidades: ruptura e reconciliação. São Paulo: Senac, 2010. p. 26. 
HASSAN, A.; NOORDIN. T. A.; SULAIMANA, S. The status on the level of environmental awareness in the concept of sustainable development amongst secondary school students. Procedia - Social and Behavioral Sciences, v. 2, n. 2, p. 1276-1280, 2010. https://doi.org/10.1016/j.sbspro.2010.03.187

KAMARUDDIN, S. M.; AHMAD, P.; ALWEE, N. Community Awareness on Environmental Management through Local Agenda 21 (LA21). Procedia - Social and Behavioral Sciences, v. 222, p. 729-737, 2016. https://doi.org/10.1016/j.sbspro.2016.05.234

KRUG. J. Mobilização Comunitária. 2. ed. São Paulo: Cortez, 1984.

LEFF, E. Ecologia, capital e cultura: racionalidade ambiental, democracia participativa e desenvolvimento sustentável. Blumenau: FURB, 2000.

LILIAMTIS, T. B.; MANCUSO, P. C. S. A geração de maus odores na rede coletora de esgotos do município de Pereira Barreto: um problema de saúde pública. Saúde e Sociedade, v. 12, n. 2, p. 86-93, 2003. https://doi.org/10.1590/S0104-12902003000200009

LINS, A. E. M.; MELO, R. A.; ROCHA, H.; OLVEIRA, M. F. A. Mobilização e participação social: pressuposto para o exercício do controle social sobre os serviços de saneamento. In: CONGRESSO BRASILEIRO DE ENGENHARIA SANITÁRIA E AMBIENTAL, 22., 14 a 18 de setembro de 2003, Joinvile. Proceedings[...]Rio de Janeiro: ABES, 2003.

MEI, N. S.; WAIA, C. W.; AHAMAD, R. Environmental Awareness and Behaviour Index for Malaysia. Procedia - Social and Behavioral Sciences, v. 222, p. 668-675, 2016. https://doi.org/10.1016/j.sbspro.2016.05.223

NEHME, E.; ROCHA, C.; SCHMIDT, C.; MOREIRA, I. Comunicação e meio ambiente: os mecanismos de comunicação utilizados pelo Parque Municipal Francisco Afonso de Melo (PNMEAM). Anuário UNESCO, n. 18, p. 45-59, 2014. http://dx.doi.org/10.15603/21760934/aum.v18n18p45-59

PACHECO, J. A. L. Movilización regionalista y nuevos poderes regionales: la fragmentación administrativa del Viejo Caldas y la creación de Risaralda. Sociedad y Economía , v. 21, p. 125-145, 2011.

PARANÁ. Secretaria de Estado da Saúde. Lei n. 13.331, de 23 de maio de 2001. Código de Saúde do Paraná. Curitiba, 2001.

PARANÁ. Decreto n. 2.460, de 08 de janeiro de 2004. Tarifa social "Homero Oguido". Curitiba, 2004.

PARANÁ. Lei n. 16.475, de 22 de abril de 2010. Programa Leite das Crianças. Curitiba, 2010.

PARANÁ. Lei n. 17639, de 31 de julho de 2013. Programa "Luz Fraterna". Curitiba, 2013.

PAVIANI, N. M. S.; FONTANA, N. M.; Oficinas pedagógicas: relato de uma experiência. Conjectura: Filosofia e Educação, v. 14, n. 2, 2009.

PEREIRA, L. F. C. B.; MAIA, M. S. S.; SOUSA, A. C. N.; MARCHESINI, A. A educação ambiental como ferramenta essencial nas intervenções em saneamento. In: CONGRESSO DE ENGENHARIA SANITÁRIA E AMBIENTAL, 23., 18 a 23 de setembro de 2005, Campo Grande. Proceedings[...] Rio de Janeiro: ABES, 2005.

PRUSS-USTUN, A.; BOS, R.; GORE, F.; BARTRAM, J. Safer water, better health: costs, benefits and sustainability of interventions to protect and promote health. Genebra: WHO, 2008. 
SANEPAR. Termo de referência para a contratação de prestação de serviços socioambientais para novos empreendimentos de esgotamento sanitário MN/AMB/0006-001. 2015. Available in: http://site.sanepar.com.br/categoria/informacoes-tecnicas/documentos-e-formularioscitados-nos-editais-de-licitacao. Access: March 26, 2019.

SANTOS, G. L. S. A.; OTA, S. N. Mobilização Social em Comunidades. Curitiba: Unilivre, 2002.

SANTOS, J. F. O saneamento como instrumento de promoção da saúde. In: BRASIL. Ministério das Cidades. Conceitos, características e interfaces dos serviços públicos de saneamento básico. Brasília, 2011. p. 357.

SHAMSOLLAHI, H. R.; ALIMOHAMMADI, M.; MOMENI， S.; NADDAFI, K.; NABIZADEH, R.; KHORASGANI, F. C.; MASINAEI, M., YOUSEFI, M. Assessment of the Health Risk Induced by Accumulated Heavy Metals from Anaerobic Digestion of Biological Sludge of the Lettuce. Biological Trace Element Research, v. 188, p. 514520, 2019. https://doi.org/10.1007/s12011-018-1422-y

SCHMITT, E. L.; HILLESHEIM, J.; CAMPIGOTO, M. C.; HENING, N.; WERNER, R. C. Programa permanente de capacitação comunitária. Blumenau: FURB, 1999.

SHEELY, R. Mobilization, participatory planning institutions, and elite capture: evidence from a field experiment in rural Kenya. World Development, v. 67, p. 251-266, 2015. https://doi.org/10.1016/j.worlddev.2014.10.024

SILVA, F. A. C.; NAVAL, L. P. A contribution to develop strategies to support the social control of sanitation activities. Ambiente \& Sociedade, v. 18, n. 1, p. 59-74, 2015. http://dx.doi.org/10.1590/1809-4422ASOC593V1812015en

SOUZA, C. M. N.; FREITAS, C. M. A produção científica sobre saneamento: uma análise na perspectiva na promoção de saúde e da prevenção de doenças. Engenharia Sanitária e Ambiental, v. 15, n. 1, p. 65-74, 2010.

SOUZA, M. J.; FERNANDES, E.; CARVALHO, L. V. Determinantes estructurales en la difusión de las patologías del agua en Brasil. Revista Problemas del Desarrollo, v. 45, p. 117-136, 2014.

STRUECKER, R.; HOFFMANN, M. G. Participação social nos serviços públicos: caracterização do estado da arte por meio da bibliometria e da revisão sistemática. REGE - Revista de Gestão, v. 24, p. 371-380, 2017. https://doi.org/10.1016/j.rege.2017.03.008

TORO, J. B.; WERNECK, N. M. D. Mobilização social: um modo de construir a Democracia e a Participação. Belo Horizonte: Autêntica, 2007.

UNITED UNION. Sustainable Development Goals. 2015. Available at: https://sustainabledevelopment.un.org/. Access: Nov. 17, 2019.

UZUN, F. V.; KELES, O. The effects of nature education project on the environmental awareness and behavior. Social and Behavioral Sciences, v. 46, p. 2912 - 2916, 2012. https://doi.org/10.1016/j.sbspro.2012.05.588

WHO. Global health risks: mortality and burden of disease attributable to selected major risks. Genebra, 2009.

YIN, R. K. Estudo de caso: planejamento e métodos. 4. ed. Porto Alegre: Bookman, 2010. 